\title{
Prospects and challenges of Online Banking Services in Pakistan: A case Study of Karachi
}

\author{
Zahid Hussain Kazi \\ Assistant Professor \\ IBA-University of Sindh-Jamshoro \\ Ghulam Murtaza Maitlo \\ Dean faculty of Commerce and Business Administration \\ SALU-Khairpur Mirs \\ Dr.Ambreen Khaskheley \\ Assistant Professor-Deptt:Economics \\ University of Sindh-Jamshoro \\ Faiz M.Shaikh \\ Assistant Professor-SZABAC-Dokri-Larkana-Sindh-Pakistan \\ faizanmy2000@hotmail.com
}

\begin{abstract}
The current research investigates Prospects and challenges of Online Banking Services in Pakistan: A case Study of Karachi.Data were collected from 400 respondent using online banking practices in Karachi Sindh-Pakistan by using simple random technique. A structural Questionnaire was developed for the reliability and validity of data.In this study data of independent variable and dependent variable were collect from the customers of different banks of Karachi.It was revealed that the model tested clearly that use of online banking is influenced by channel convenience, perceived risk, security perception, prior internet knowledge and information on online banking. The results also determine that demographic factors also impact significantly on online banking. Finally, this paper suggests that an understanding the factors affecting intention to use internet banking is very important to the practitioners who plan and promote new forms of banking in the current competitive market
\end{abstract}

\section{Council for Innovative Research}

Peer Review Research Publishing System

Journal: International Journal Of Management \& Information Technology

Vol. 10, No 5

editorsijmit@gmail.com

www.ijmit.com 
Introduction. According to Kayode (2008) said that customers can also access different banking services such as transfer of funds from one account to another, also do transactions of different banks customers and check their accounts balance through internet banking and e-commerce. Intoday modern era, every customer has computer access at their homes and they can easily browse information related with transaction. In addition,Ram and Sheth (1998)stated that the market failure of innovation is major caused because of customer dissatisfaction and resistance. The most popular system in online banking system is ATM (automated teller machine) which helps the customer to carry out their banking transactions and easily avail all banking information Technology is playing very important role in the competitive era of financial industry. The recent developments in the technology have created totally new service concept and service environment. Technology has changed the nature of buying and selling of services. One of the fundamental changes in the banking industry has been the movement of consumer from traditional to e-banking such as internet, telephone and mobile phones in private banking.

E-commerce and internet banking is nowadays prioritized by many financial institutions. Internet banking and e-commerce is also known as providing new services and products in banking sector. By the help of internet banking and e-commerce small banks can creates opportunities to compete same as larger banks are doing. Customers who want more quality products and services in innovative way can avail these services quickly.

. Due to more advancement in internet technologies, online banking nowadays play very crucial role in e-payment area and also provide online transaction platform to customers, support many e-commerce business such as online shopping, online auction and internet stock as well. In contrast, Hood 1979; Murphy, 1983; said that the demographic profiles of customers and their way to use ATM shows high association. However, Stevens et al., 1986 found that there is significant relation between customer usage pattern of ATM and psychographic profiles.

\section{Conception of Online Banking}

The sign for the recent home online banking services were distance banking services over the electronic media from the early $80 \mathrm{~s}$. The term online become known in late 80 s and refers for the use of workstation, keyboard and TV (or Monitor) to access the banking organism usingthe phone line. 'Home Banking' can also refer to use of various numeric keypads to send the instructions to the bank using tones of phone line.

Online services get started from New York in 1981when city's four major banks (Citibank, Chase, Manhattan, Chemical and Manufacturers Hanover) offered home banking services using videotext system.Videotexts system were well known system used in early 1970 to 1980 , that provides the interactive content on a television to the end user of information in computer-like format.

\subsubsection{Online Banking in Pakistan}

Online banking is the most current and recent advance technology in Pakistan like ATM, credit cards and debit cards internet banking is the now days banking product and services. In the Pakistan first took start from the MCB they introduce ATM and credit card facility in mid-1990 the online banking supported by transition of the electronic banking ordinance 2002 by the government of Pakistan. Legal respect of digital signature that related with risk associated documents with the exercise of electronic technology in business. In recent stationmostly all Pakistani banks has their own network system. Issuing debit and credit cards collectively operating banks ATM network with each other's

Mostly in the Pakistan ATM and online banking debit and credit cards have the greater then 2000.the annual report of 2005 State bank of Pakistan describe the ATM facility provide by domestic banks and the credit card facility provide by foreign banks like Stander charter and Citi banks control on credit card facility in Pakistan and overall 95\% of total amount of transitions.

In Pakistan online banks system adopted little bit late compared to other countries, but they try to do competition with them. Now days Debit and Credit card facility frequently are using by the account holders. Presently 28 commercial banks providing online banking facility in Pakistan $74 \%$ of Pakistani banks are operating online banking services. As already discuss MCB took creativity introduce ATM and credit card facility according to report of SBP 2011 currently 4,737 ATM machines are working in Pakistan. In Pakistan Allied banks Limited has 573 ATMs. Allied bank is largest bank in online banking system establish 800 online branches in Pakistan. Mostly commercial banks of Pakistan are offering computerized banking services to their customer and all linked with each other order to operating ATMs.

Online banking systems reduce the cost of operations like physical appearance of banks and workers mostly in the Pakistan e banking creativities and utilize the technology benefits and produce other many benefits in the banking system Pakistan has been among the late inter in the online banking. First ATM was start in 1999 and in 2000 internet banking was introduce (Ahmed,2006).

Financial institutions of Pakistan will also have to increase suitable protection to deal with the operational risks. $90 \%$ of the banks in urban areas using computerized system by 2006.different banks offering different facility like fund transfer in the other banks. Some bans also provide mobile banking facility in which we can transfer utility bills can do payment through mobile phone.

Online banking is quite important for everyone in current technological era, because nowadays everyone wants to get their works quickly, so for that internet banking is a viable source to get their work done quicker as compare to the traditional one. To deal with online transactions some of the factors should be keep in the mind for the smooth operations of your 
business, Influence of Information on Online Banking, Channel Convenience, Prior Internet Knowledge, Security Perception and Perceived Risk.

Shanmugan.B and Guru.B.K. (2003) defines in way that the closely worldwide connectivity offered by internet has made IT an invaluable tool of business. These types of advancements have shaped a new type of economy, which may be called digital economy. This fast emerging economy is bringing with it rapidly changing technologies, created the awareness for all the areas of business and forming cybernetic supply chains and new methods of businesses and service delivery channels such as online banking.The term online banking/e-banking has been used in literature in various ways, to some extent electronic banking refers to several types of services through which bank's customers can request for the information and carry out most retail banking services through internet, television or cell phones. Online banking means providing the banking products and services quickly to their customers through electronic medium, interactive communication channels.

Basel Committee (1998) has comprehensively defines the online banking as the provision of retail and small value banking products and services through electronic channels, such products and services can include lending, taking deposit, account's management, e-billing payments and services such as electronic money.

According to Byers, R.E and Lederer, P.L. 2001, that e-business literature has studied the occurrence of the online banking from various angles. Some research has explored the progression and adoption of online banking, while others define the challenges and benefits to be enlarged form online banking services which are concerned for organization. From the last two decades banking sector has chosen the new type of medium to provide the servicesbased on information technology with the help of internet for the sake of customer preferences and needs, competition has been increased from non-banks, changes in social trends and demographics, and deregulation from government for financial service sector.

According to Shah.Mand Clarke.S.(2009) the adoption of new IT application is largely influenced by the some of the factors such as overall organizational attitude and culture as well infrastructure and technical elements.

\subsection{Demographics Characteristics}

Demographic factors also linked with the adoption of different banking channels, mostly internet banking (Al-Ashban and burney, 2001; Karjaluoto et al, 2002; Sathye, 1999). For examples people with high education and have good knowledge about the computer and their system work and have good information and skills. These abilities are critical in the situation of internet banking and therefore a relationship between formal education and adoption is submitted. According to Flavia ' $n$ et al.(2006) mostly women less like to conduct their banking activities online.one research in Turkey also show according to the Akinci etal.(2004) mostly mid age consumer are more likely to conduct their banking activities online compare to the younger and older consumer to use internet banking.(Karjaluoto et al.,2002; Mattila et al.,2003; Sathye,1999) appearances that those who belong to upper class they more like to using online banking system thy feel it's less costly and time saving tools. It's usually familiar that demographic factors have excessive impact on consumer behavior and attitudes concerting online banking (Sathye, 1999; Karjaluoto et al., 2002) analysis that there is significant different on age, gender and income towards using internet banking. (Davis et al., 1989) define the degree in which a person trusts that using a particular system improve his or her job and also increase their work performances.

Mostly general factor of user's is attitude towards technology, and their using experience and getting information from the people it support to use easy and increasing the information and way to using that in different contexts. Easy of using consumer perception that using internet banking involves fewer efforts these for that customer who believe that system using is easy according to the (Davis, 1989. 1993).

\subsection{Channel Convenience}

Convenience has been identified that adoption is very important issue for new technology (ACNielsen, 2005, and Pew 2003 defined convenience is good for the consumer product because they need time and physical efforts to purchase product after that some other definition of convenience focus on resources such as time and efforts required in shopping also for that they produce product (Brown, 1990).other researchers, also forcing on the concept of convenience to nonshopping activities also. It's connected to the graphic view ofinternet compare to mobile banking (black et al.2002) besides these 24 services are presented (Gerrad and Cunningham, 2003; Liao and Cheung.2002).easily do home contact (Gerrard and Cunningham, 2003) world wide access and worldwide services also available (Liao and Cheung, 2002),time saving and can use through the internet banking, in previous author discussing retail banking is a completive advantage for retail channel in the services (Polatoglu and Ekin, 2001:Gerrard and Cunningham, 2003) convenience is one factor in transaction channel and determined the key channel transaction channel preferences and doing satisfaction. In this study also indicated that the support convenience was the most important variables adoption of all online activities. Convenience recognized by many studies that is an important adoption factor (ACNielsen,2005;Pew,2003) A us study show that conveniences is important factor for internet banking 24 hours access and time saving (Pew,2003).Chung and Paynter (2002)found many of people not interested to using internet banking they did not need high convinces. Accessibility, which related to convenience also found an important factor (Ramsay and Smith, 1999). 


\subsection{Theoretical framework}

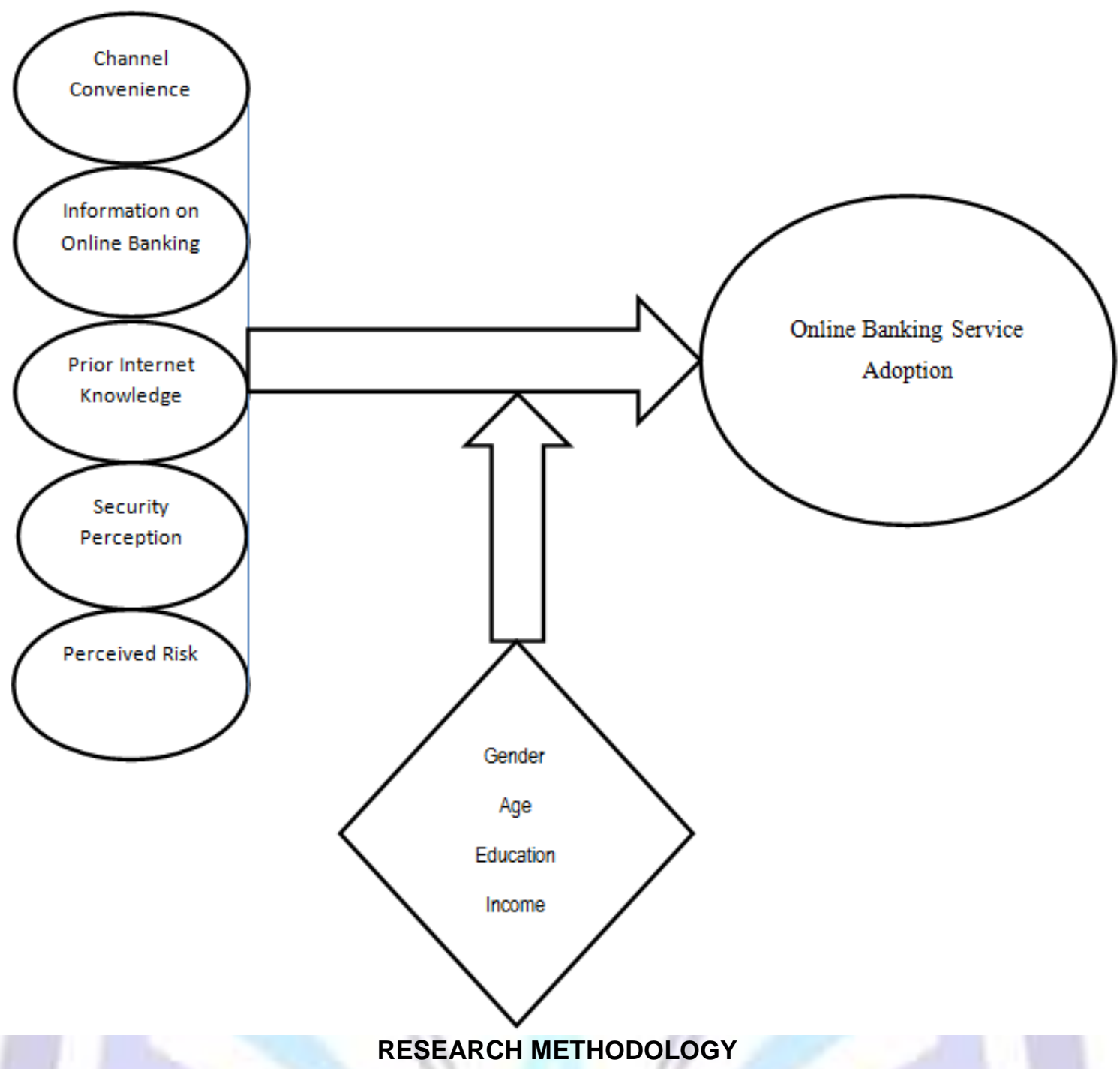

Data were collected from 200 respondent using online banking practices in Karachi Sindh-Pakistan by using simple random technique. A structural Questionnaire was developed for the reliability and validity of data. In this study data of independent variable and dependent variable were collect from the customers of different banks of Karachi.

The questionnaire has been used to collect the information for respondents,For measurement, we will quantify the respondent's response with the help of likert 5 point scale. Ranging from ( $1=$ strongly disagree, $5=$ strongly agree)

\section{DATA ANALYSIS}

In the administration of survey, participants' demographics data were collected along with Adoption of online banking and Channel Convenience, Information on online banking, Perceived Risk, Prior internet Knowledge, Security Perception factors data. The motive of collection of these demographic data was to knowing the general information about the customers of Banks. Those demographics data consisted of participants' age, gender, education and occupation, further analysis consist of reliability, comparison of co-relation of various variables and regression.

\section{Reliability}

Table: .1

\begin{tabular}{|r|r|}
\hline \multicolumn{2}{|c|}{ Reliability Statistics } \\
\hline $\begin{array}{c}\text { Cronbach's } \\
\text { Alpha }\end{array}$ & N of Items \\
\hline .899 & \\
\hline
\end{tabular}




\section{Interpretation:}

This table shows the .899 Cronbach's Alpha, which is more than the required standard reliability of .660 that means the instrument of this research is quite reliable

\section{Frequencies}

The gender of responding customers consists of $56 \%$ males (169) and $44 \%$ females (133)

\section{(See following table 2.1)}

Table: 2.1

\begin{tabular}{|c|c|c|c|c|}
\hline \multicolumn{5}{|c|}{ Gender } \\
\hline & Frequency & Percent & Valid Percent & $\begin{array}{c}\text { Cumulative } \\
\text { Percent }\end{array}$ \\
\hline Male & 169 & 56.0 & 56.0 & 56.0 \\
\hline Female & 133 & 44.0 & 44.0 & 100.0 \\
\hline Total & 302 & 100.0 & 100.0 & \\
\hline
\end{tabular}

\section{Interpretation:}

The research demographics result show that response received $169(56 \%)$ were males and $133(44 \%)$ were the females. Total number of respondents was 302 .

Table: .2.2

\begin{tabular}{|l|r|r|}
\hline Age Group & Frequency & \multicolumn{1}{|c|}{ Percent } \\
\hline $15-20$ & 45 & $15 \%$ \\
\hline
\end{tabular}

\begin{tabular}{|l|r|r|}
\hline $21-25$ & 105 & $35 \%$ \\
\hline $26-30$ & 112 & $37.10 \%$ \\
\hline $31-35$ & 40 & $13.20 \%$ \\
\hline Total & 302 & 100.0 \\
\hline
\end{tabular}

\section{Gender}

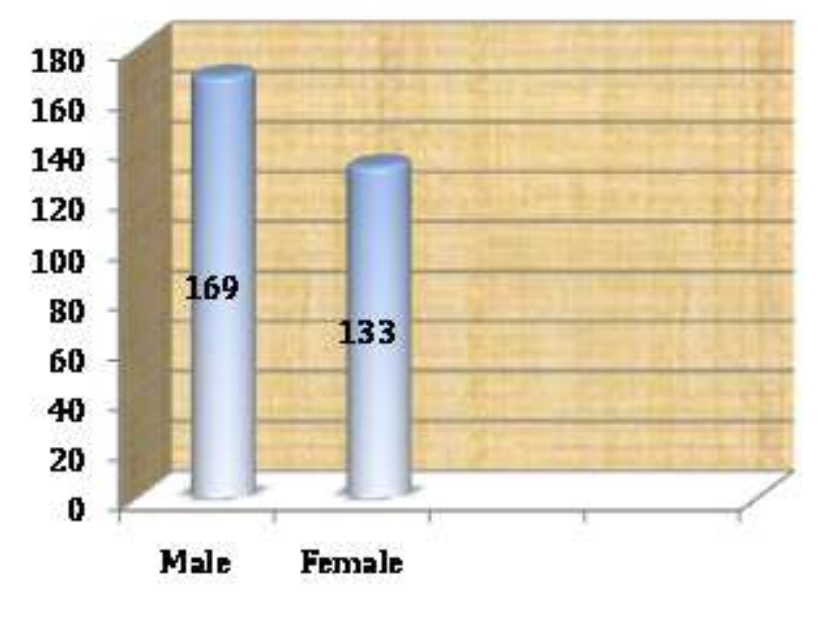


Graph 4.2.2

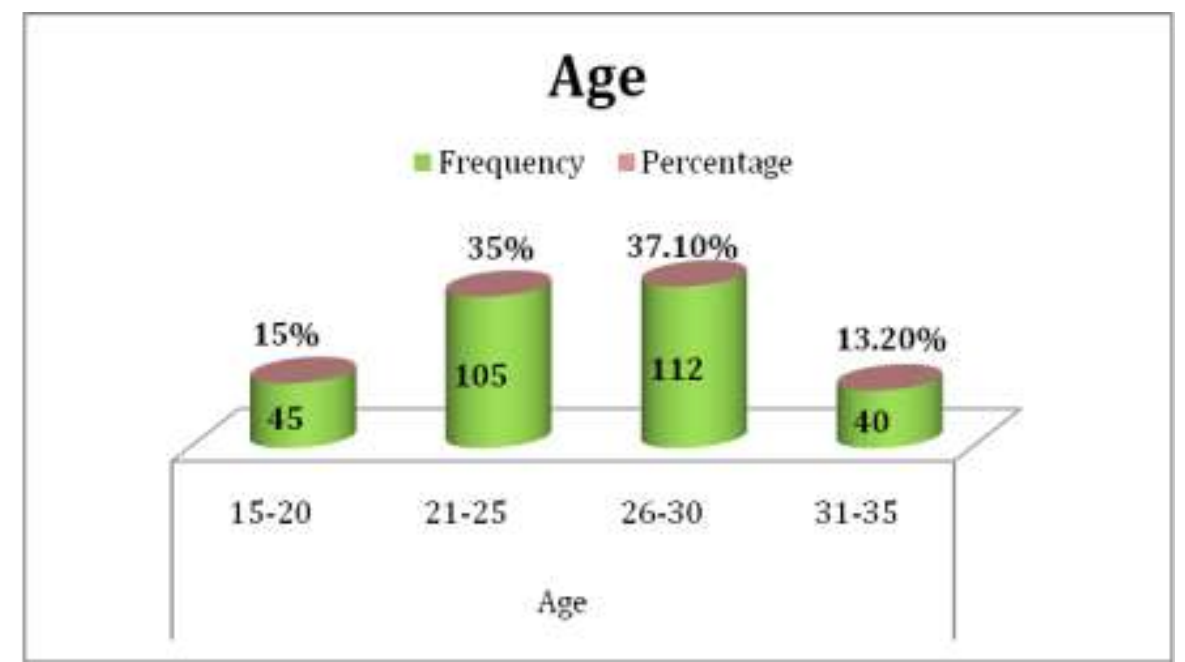

\section{Interpretation:}

Table no: 4.2 .2 shows the age of the respondants the total respondants were 30 out of which $15 \%$ lies under the age of 15 years to 20 years, $35 \%$ between 21 years to 25 years, $37.10 \%$ between 26 years to $30,13.20 \%$ between 31 years to 35 years.

Table: 4.2 .3

\section{Education}

\begin{tabular}{|l|c|c|c|c|}
\hline & Frequency & Percent & Valid Percent & $\begin{array}{l}\text { Cumulative } \\
\text { Percent }\end{array}$ \\
\hline High School & 31 & 10.3 & 10.3 & 10.3 \\
College & 38 & 12.6 & 12.6 & 22.9 \\
Graduation & 130 & 43.0 & 43.0 & 65.9 \\
Masters & 103 & 34.1 & 34.1 & 100.0 \\
Total & 302 & 100.0 & 100.0 & \\
\hline
\end{tabular}

Graph4.2.3

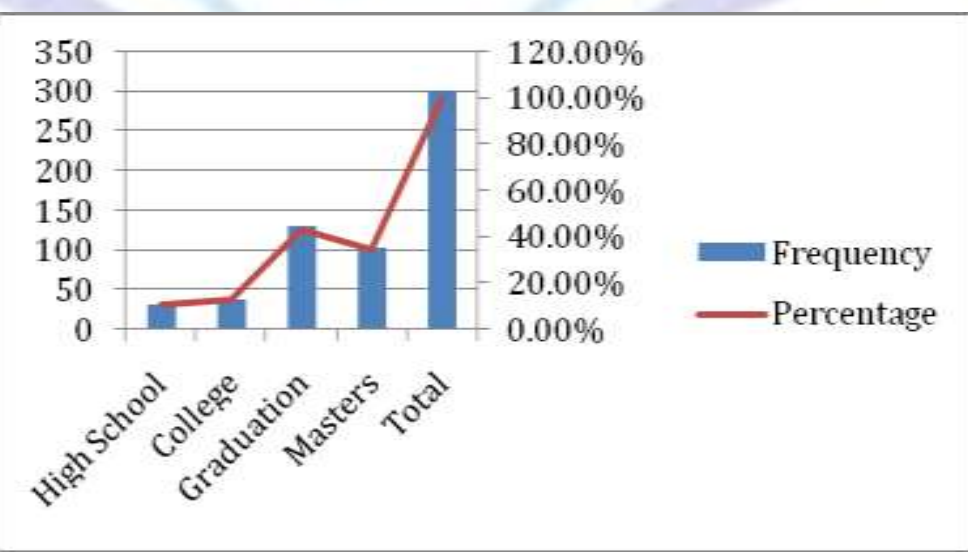




\section{Interpretation:}

After the categorization of the respondents in male and female, and furthermore it was divided regarding their standard in which they study graph no 4.2 .3 which shows that $10.3 \%$ from High School along with the frequency of 31 , while $12.6 \%$ are from College, that has frequency of $38.43 \%$ from graduation along with the frequency of 130 , while $34 \%$ are from Masters.

Table: 4.2.4

Occupation

\begin{tabular}{|l|c|c|c|c|}
\hline & Frequency & Percent & Valid Percent & $\begin{array}{c}\text { Cumulative } \\
\text { Percent }\end{array}$ \\
\hline Student & 112 & 37.1 & 37.1 & 37.1 \\
Independent & 44 & 14.6 & 14.6 & 51.7 \\
Blue-collar worker & 62 & 20.5 & 20.5 & 72.2 \\
Middle Staff Employee & 64 & 21.2 & 21.2 & 93.4 \\
Executive & 20 & 6.6 & 6.6 & 100.0 \\
Total & 302 & 100.0 & 100.0 & \\
\hline
\end{tabular}

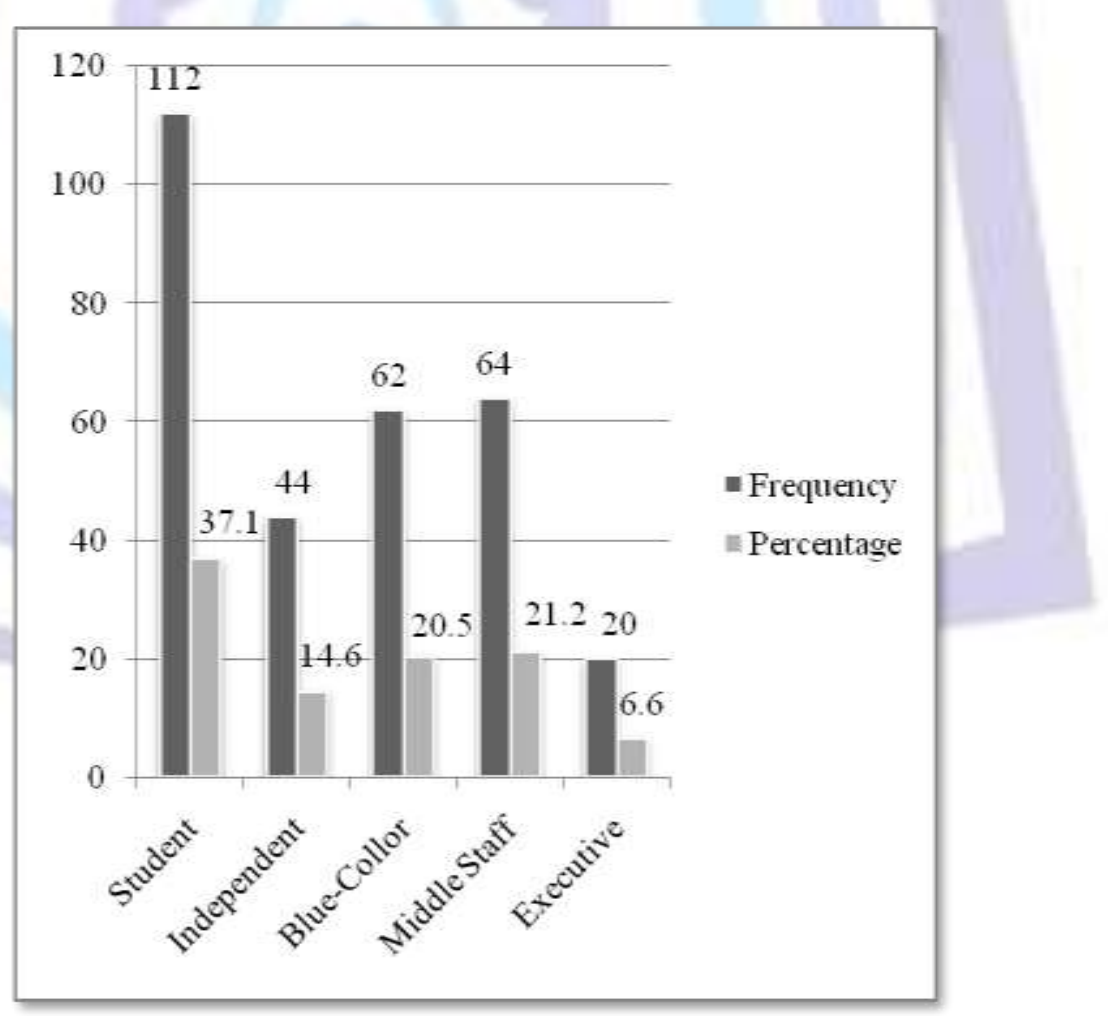

Graph 4.2.4 


\section{Interpretation:}

After the categorization of the respondents regarding their standard in which they study graph no 4.2 .4 which shows that $37.1 \%$ from Students along with the frequency of 112 , while $14.6 \%$ are from Independent, that has frequency of 44 . $20.5 \%$ from Blue-Collar along with the frequency of 62 , while $64 \%$ are from idle Staff has frequency of 64 . While the executive has percentage of 6.6 and frequency of 20 .

\subsection{Crosstabulation}

Table: 4.3.1

\section{Gender * Education Cross tabulation}

Count

\begin{tabular}{|ll|c|c|c|c|c|}
\hline & \multicolumn{5}{c|}{ Education } & \\
\cline { 3 - 6 } & & High School & College & Graduation & Masters & Total \\
\hline Gender & MALE & 15 & 23 & 75 & 56 & 169 \\
& FEMALE & 16 & 15 & 55 & 47 & 133 \\
\hline
\end{tabular}

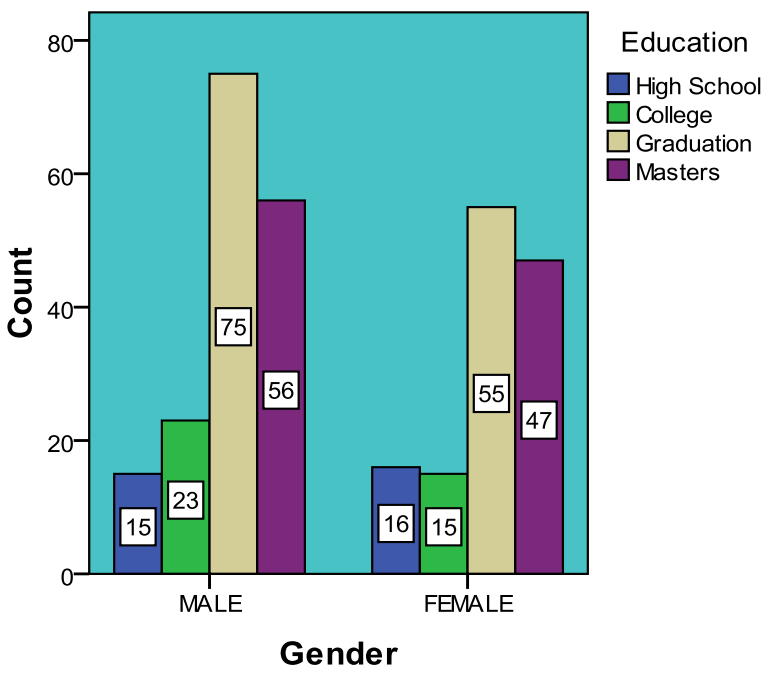

Graph 4.3.1

\section{Interpretation:}

The graph no: 4.3 .1 shows that there were actually 302 respondents in which the female respondents were 16 in high school, 15 from college, 55 from graduation and 47 from masters, while the male respondents there were 75 from graduation. 
Table: 4.3.2

Gender * Age Cross tabulation

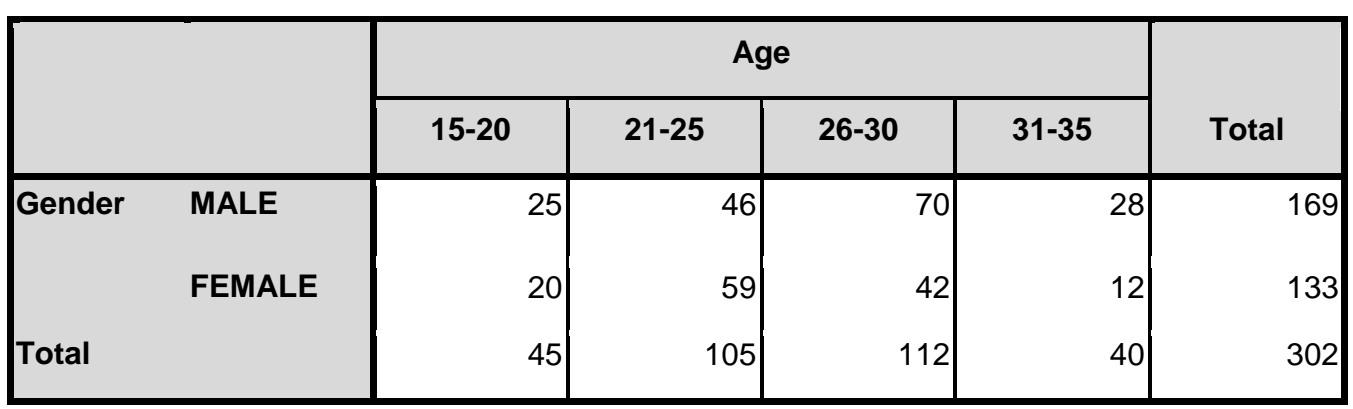

Graph: 4.3.2

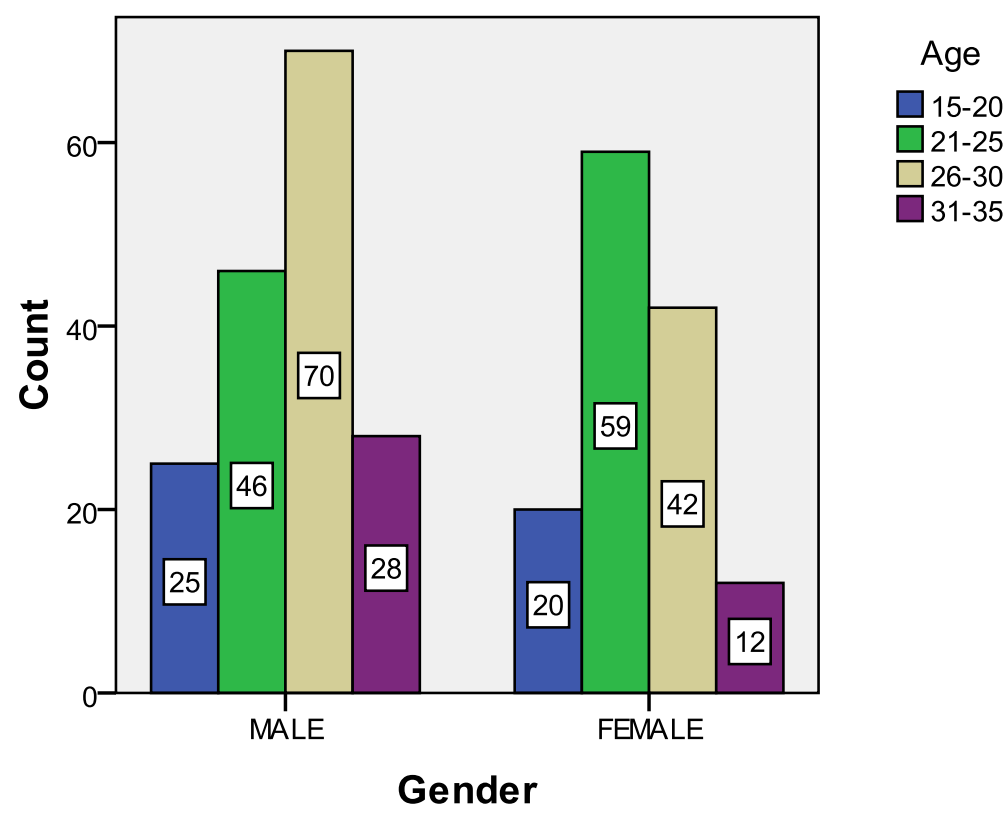

\section{Interpretation:}

Above graph 4.3.2 depict that there were 302 respondents of which female respondents were 59 from $21-25,42$ female respondents were from 26-30 age group, 12 were from third age group of 31-35 and 20 were from the 15-20 age group.

While 25,46,70,28 male respondents were from the age group of 15-20, 21-25, 26-30, 31-35 respectively. 


\subsection{Descriptive Statistics}

Table 4.4.1

\begin{tabular}{|c|c|c|c|}
\hline & N & Mean & Std. Deviation \\
\hline Channel & 302 & 1.9512 & 1.82839 \\
Security Perception & 302 & 3.5841 & .71918 \\
Perceived Risk & 302 & 3.6265 & .38419 \\
Prior Internet Knowledge & 302 & 3.1280 & .55400 \\
Information of Online & 302 & 3.9305 & .57378 \\
Adoption of Online Banking & 302 & 3.9296 & .55680 \\
& 302 & & \\
\hline
\end{tabular}

\section{Interpretation:}

The table 4.4.1 provides the important and relevant information, and $\mathrm{i}$ have made a benchmark for mean which is 3 , so if the mean of the variables will be less than 3 it will be considered towards the disagreed side, while when the mean of the variables will greater the benchmarks of 3 will be considered towards the agreed side, as the it is showed in the above given table that the channel convenience variable has less mean of 1.95 which shows people of Karachi are not agree with adopting the online banking due to the channel convenience.

\subsection{Bivariate Analysis}

Table 4.5.1

\section{Correlations}

\begin{tabular}{|c|c|c|c|c|c|c|}
\hline & Channel & $\begin{array}{l}\text { Security } \\
\text { Perception }\end{array}$ & $\begin{array}{l}\text { Perceived } \\
\text { Risk }\end{array}$ & $\begin{array}{l}\text { Prior Internet } \\
\text { Knowledge }\end{array}$ & $\begin{array}{l}\text { Information of } \\
\text { Online }\end{array}$ & $\begin{array}{c}\text { Adoption of } \\
\text { Online Banking }\end{array}$ \\
\hline Channel Convenience & & $.155^{\times \pi}$ & .083 & .041 & .095 & .092 \\
\hline Security Perception & & 1 & .103 & .100 & $.166^{\star \pi}$ & $.176^{\pi x}$ \\
\hline Perceived Risk & & & 1 & .002 & .303 & $.236^{\prime \prime}$ \\
\hline $\begin{array}{l}\text { Prior Internet } \\
\text { Knowledge }\end{array}$ & & & & 1 & $.118^{x}$ & .085 \\
\hline $\begin{array}{l}\text { Information of Online } \\
\text { Banking }\end{array}$ & & & & & 1 & $.699^{n 1}$ \\
\hline $\begin{array}{l}\text { Adoption of Online } \\
\text { Banking }\end{array}$ & & & & & & \\
\hline
\end{tabular}

**. Correlation is significant at the 0.01 level (2-tailed).

*. Correlation is significant at the 0.05 level (2-tailed). 
Interpretation: Above table demonstrate that dependent variable Adoption of Online Banking has valuable relationship of .699 with Information of online banking variable and results shows that there is greater relationship of .699 between adoptions of online banking with information of online banking variable. In above table result shows that there is minimum relationship between the information of online banking with prior internet knowledge variable.

\subsection{Regression}

\section{Table 4.6.1}

\section{Model Summary}

\begin{tabular}{|l|r|r|r|r|}
\hline Model & \multicolumn{1}{|c|}{$\mathbf{R}$} & R Square & \multicolumn{1}{|c|}{$\begin{array}{c}\text { Adjusted R } \\
\text { Square }\end{array}$} & $\begin{array}{l}\text { Std. Error of the } \\
\text { Estimate }\end{array}$ \\
\hline 1 & $.702^{\mathrm{a}}$ & .493 & .484 & .39995 \\
\hline
\end{tabular}

a. Predictors: (Constant), Information of Online, Channel, Prior Internet Knowledge, Security Perception, Perceived Risk

\section{Interpretation:}

The table 4.6.1 shows that, there is insignificant impact of independent variables on dependent variable because the $R^{2}$ is .484 which is less than .6 which is the benchmark. The $R$ value in the table shows the correlation value among the dependent variable Adoption of Online Banking) and independent variables (Information of Online, Channel, Prior Internet Knowledge, Security Perception.

\section{CONCLUSION}

As we know that there are many factors which could influence on the adoption of online banking. This research is based on five important factors that are Channel Convenience, Perceived Risk, Security Perception, and Prior Interne knowledge, Information about online banking.

Today in era of Information technology every business wants to deliver their products and service via various electronic channels. This research is conducted to find out the influence of Channel Convenience, Information on online banking, Perceived Risk, Prior internet Knowledge, Security Perception (Independent variables) upon Online Banking Service Adoption (Dependant Variable).

On the basis of result we came to the conclusion that information about the online banking has the positive influence as well positive correlation with adoption of online banking in Karachi.

\subsection{FUTURE RESEARCH}

In this research we had taken the five variables those are Channel Convenience, Information on online banking, Perceived Risk, Prior internet Knowledge, Security Perception (Independent variables) upon Adoption of Online Banking Service (Dependant Variable).on the basis of model summary result we are recommending that in future research should take into account different variable which we had not taken into account in this research.

\section{REFERENCES}

1. Jyväskylä Studies In Business And Economics 18, Heikki Karjaluoto Electronic Banking In Finland, University Of Jyväskylä Jyväskylä 2002.

2. A General View On The E-Banking,F.Sameni Keivani1+, M.Jouzbarkand1, M.Khodadadi1, Z.Khalili Sourkouhi11dept. Accounting, Islamic Azad University, Roudsar And Amlash Branch, Roudsar, Iran.

3. A Study On Attitude And Intention Towards Internet Banking With Reference To Malaysian Consumers In Klang Valley Region, The International Journal Of Applied Management And Technology, Vol 6, Num 1.

4. African Journal Of Business Management Vol.2 (1), Pp. 032-040, February, 2008, Available Online At Http:/Www.Academicjournals.Org/Ajbm Issn 1993-8233 @ 2007 Academic Journals.

5. Kumbhar V. M., Factors Affecting The Customer Satisfaction In E-Banking: Some Evidences Form Indian Banks Management Research And Practice Vol. 3 Issue 4 (2011) Pp: 1-14 1 Management Research And Practice Volume.

6. Understanding Consumer Adoption Of Internet Banking:

7. An Interpretive Study In The Australian Banking Context; Journal Of Electronic Commerce Research, Vol 7, No.2, 2006.

8. Journal Of Internet Banking And Commerce, April 2008, Vol. 13, No.1.

9. A Study On Attitude And Intention Towards Internet Banking With Reference To Malaysian Consumers In Klang Valley Region; The International Journal Of Applied Management And Technology, Vol 6, Num 1.

10. Jyväskylä Studies In Business And Economics 18, Heikki Karjaluoto Electronic Banking In Finland, University Of Jyväskylä Jyväskylä 2002. 
11. A General View On The E-Banking,F.Sameni Keivani1+, M.Jouzbarkand1, M.Khodadadi1, Z.Khalili Sourkouhi11dept. Accounting, Islamic Azad University, Roudsar And Amlash Branch, Roudsar, Iran.

12. A Study On Attitude And Intention Towards Internet Banking With Reference To Malaysian Consumers In Klang Valley Region, The International Journal Of Applied Management And Technology, Vol 6, Num 1.

13. African Journal Of Business Management Vol.2 (1), Pp. 032-040, February, 2008, Available Online At Http:/Www.Academicjournals.Org/Ajbm Issn 1993-8233 @ 2007 Academic Journals.

14. Kumbhar V. M., Factors Affecting The Customer Satisfaction In E-Banking: Some Evidences Form Indian Banks Management Research And Practice Vol. 3 Issue 4 (2011) Pp: 1-14 1 Management Research And Practice Volume.

15. Understanding Consumer Adoption Of Internet Banking:

16. An Interpretive Study In The Australian Banking Context; Journal Of Electronic Commerce Research, Vol 7, No.2, 2006.

17. Journal Of Internet Banking And Commerce, April 2008, Vol. 13, No.1.

18. A Study On Attitude And Intention Towards Internet Banking With Reference To Malaysian Consumers In Klang Valley Region; The International Journal Of Applied Management And Technology, Vol 6, Num 1

19. Factors Influencing The Adoption Of Internet Banking In Tunisia; International Journal Of Business And Management Vol. 6, No. 8; August 2011.

20. International Review Of Business Research Papers Volume 6. Number 4. September 2010. Pp. 145 - 156.

21. African Journal Of Marketing Management Vol. 3(10), Pp. 261-269, October 2011;Available Online At Http:/Www.Academicjournals.Org/AJMM , ISSN 2141-2421 @2011 Academic Journals.

22. Customer Satisfaction On E-Banking (A Study With Special Reference To Mayiladuthurai).

23. Journal Of Public Administration And Governance, ISSN 2161-7104; 2011, Vol. 1, No. 1.

24. Marketing and e-commerce department of business administration and social sciences divisional of industrial marketing and e-commerce 2008;099- ISN:1653-0187- ISRN: LTU-PB-EX-08/099 -SE.

25. Al-Ashban, A.A., and Burney, M.A. (2001). Customer adoption of tele-banking technology: the case of Saudi Arabia. International Journal of Bank Marketing, Vol. 19 No. 5, pp. 191-200.

26. Karjaluoto, H., Mattila, M., and Pento, T. (2002).Factors underlying attitude formation towards online bankingin Finland. International Journal of Bank Marketing, Vol. 20 No. 6, pp. 261-72.

27. Sathye, M. (1999). Adoption of Internet banking by Australian consumers: an empirical investigation.International Journal of Bank Marketing, Vol. 17 No. 7, pp. 324-34.

28. Akinci, S., Aksoy, S., and Atilgan, E. (2004).Adoption of internet banking among sophisticated consumersegments in an advanced developing country.International Journal of Bank Marketing, Vol. 22No.3, pp.212-32.

29. Mattila, M., Karjaluoto, H., and Pento, T. (2003). Internet banking adoption among mature customers: early majority or laggards?. Journal of Services Marketing, Vol. 17 No. 5, pp. 514-28.

30. Davis, F. D. (1989). Perceived Usefulness, Perceived Ease of Use, and User Acceptance of InformationTechnology. MIS Quarterly, 13, pp.319-340.

31. Black, N.J., Lockett, A., Winklhofer, H., and McKechnie, S. (2002). Modelling consumer choice of distribution channels: an illustration from financial services. The International Journal of Bank Marketing, Vol. 20 No. 4, pp.161-73

32. Brown, L. G. (1990). Convenience in services marketing.Journal of Service Marketing, 4, 53-59.Burr W. (1996).WielnformationstechnkdieBankorganisationverändernKönnte. Bank and Market, Vol.11, pp.28-31.

33. Gerrard, P., and Cunningham, J.B. (2003). The diffusion of Internet banking among Singapore consumers.International Journal of Bank Marketing, Vol. 21 No. 1, pp. 16-28.

34. Liao, Z., and Cheung, M.T. (2002). Internet-based e-banking and consumer attitudes: an empirical study.Information\& Management, Vol. 39 No. 4, pp. 283-95.

35. Polatoglu, V.N., and Ekin, S. (2001). An empirical investigation of the Turkish consumers' acceptance ofinternet banking services. International Journal of Bank Marketing, Vol. 19 No. 4, pp. 156-65.

36. Bhatnagar, A., Misra, S., \&Rao, H.R. (2000).On risk, convenience, and internet shopping behavior. Communications of the ACM, 43(11), pp. 98-114

37. Pavlou P.A. (2003). Consumer acceptance of electronic commerce: integrating trust and risk with the technology acceptance model. International Journal of Electronic Commerce, 7(3), 69-103.

38. Bauer R.A. (1960). Consumer behaviour as risk taking, In Hancock, R.F. (Ed), Proceedings of the 43 rdConference of the American Marketing Association, American Marketing Association, Chicago, IL, pp. 389-98.

39. Jarvenpaa, S., and Tractinsky, N. "Consumer Trust in an Internet Store: A Cross-Cultural Validation," Journal of Computer Mediated Communication, (5:2) 1999, pp. 1-35.

40. Koufaris, M. \& Hampton-Sosa, W., 2004, - The Development of Initial Trust in an Online Company by New Customers, II Information and Management, 413, 377-397.

41. Cunningham, L., Gerlach, J., \& Harper, M. 2005. Perceived risk and e-banking services: An analysis from the perspective of the consumer. Journal of Financial Services Marketing, 10 (2), 165-178

42. Littler, D. \&Melanthiou, D. 2006. Consumer perceptions of risk and uncertainty and the implications for behavior towards innovative retail services: the case of internet banking. Journal of Retailing and Consumer Services, 13, 431-443.

43. Salam, A.F., Rao, H.R. \&Pegels, C.C. 2003. Consumer-perceived risk in e-commerce transactions. Communications of the ACM, 46 (12), 325-331. 


\section{ISSN 2278-5612}

44. Schlosser, A.E., White, T.B. \& Lloyd, S.M. 2006.Converting web site visitors into buyers: how web site investment increases consumer trusting beliefs and online purchase intentions. Journal of Marketing, 70, 133-148.

45. Mayer, R. C., Schoorman, F. D. \& Davis, J. H.1995. An integrative model of organizational trust.Academy of Management. The Academy of Management Review, 20 (3), 709-734.

46. Chan, S.-C., \& Lu, M.-t. (2004). Understanding Internet Banking Adoption and Use Behavior: A Hong Kong Perspective. Journal of Global Information Management, 12(3), 21-43.

47. Cheng, T., Lama, D. and Yeung, A. (2006), "Adoption of internet banking: an empirical study in Hong Kong", Decision Support Systems, 42 (3),1558-72.

48. Davis, F.D. (1989) "Perceived Usefulness, Perceived Ease of Use, and User Acceptance of Information Technology," MIS Quarterly, Sept, 319-340.

49. Ahmed, A. (2006), "Policies \& Regulations for Expanding e-banking to the Poor", The First

a. Micro Finance Bank Ltd, 24 (1), pp. 1-8. 